\title{
Comparative Analysis of the Characteristics of Public Procurement Systems in Germany, France and Romania
}

Ionel PREDA ${ }^{1}$

\begin{abstract}
In public procurement, an important role is played by the analysis of the way public procurement takes place in other European Union (EU) countries.

Although public procurement in EU Member States are governed by the same general rules established by a series of Directives that Member States have to transpose into national law, there are a number of significant differences and characteristics between public procurement systems.

These differences are very important as they can lead to the identification and adoption of measures that can generate a number of effects, such as: increasing the efficiency of the use of budget funds, reducing the time of a procurement procedure, reducing the number of complaints, increasing the number of tenderers that participate in procurement procedures, encouraging the participation in procedures of small and medium enterprises, etc.

The article describes an analysis of the main features of public procurement in the two most important EU member states, namely Germany and France, which are analysed in comparison with the public procurement system in Romania.
\end{abstract}

Keywords: public procurement, procurement procedure, principles of public procurement, value threshold, award criterion, assessment factor.

JEL classification: C46, H57, H83

DOI: $10.24818 /$ RMCI.2019.1.63

\section{Introduction}

From an economic point of view, the public procurement system in the European Union is very high, because its total annual amount (around 2 trillion Euro) is of approx. 14\% of the GDP of the whole region, while at EU level there are over 250,000 contracting authorities. Considering the total value of EU procurement, an increase in efficiency of only $1 \%$ can lead to savings of approx. 20 billion Euro per year (EC, 2019).

In the European Union (EU), the main target of the procurement system was to open public procurement to trade between Member States. Trade regime in the EU is now recognized as one of the oldest, most valuable and comprehensive in the world. Public procurement field in the EU is regulated centrally to achieve a free market. This is based on the theory of competitive advantage, according to which a state has a competitive advantage in producing products and services if it

${ }^{1}$ Ionel Preda, The Bucharest University of Economic Studies, Email: predaionel4@ gmail.com, Telephone: 0040724811741

$63 \quad$ Review of International Comparative Management

Volume 20, Issue 1, March 2019 
produces them relatively efficiently compared to other states. The main disadvantage of the EU procurement system consists in limiting the freedom of governments to implement national procurement policies (to obtain the highest value for the funds spent) in a manner that best suits the particularities of the Member States, making it difficult to adapt supranational rules to specific circumstances of each region / state (Thai, K., V. et al., 2009).

\section{The public procurement system in Germany}

The Federal Office for Technology and Defence (BWB - Bundesamt für Wehrtechnik und Beschaffung) is the largest federal purchaser (BWB, 2006). BWB acquires all the necessary equipment and supplies for Germany's Federal Army, such as: complex weapons systems, armoured vehicles, airplanes, ships, soldiers' equipment and uniforms.

The second largest federal purchasing authority is the Procurement Agency of the Federal Ministry of the Interior (BeschA - Beschaffungsamt des Bundesministeriums des Inneren). It purchases products / services for a number of 26 federal organizations (federal police, federal offices and federations). Among the products / services purchased are: office equipment, consulting, research and development for vehicles, boats, police helicopters, medicines for humanitarian activities (Procurement Agency of the Federal Ministry of the Interior, 2005).

According to Solbach, T. (2018), the main features of the procurement system in Germany in the year 2018 are:

- the number of contracting authorities: approximately 30,000;

- the annual number of procedures performed: approximately 2.4 million;

- estimated annual procurement value: between 280 and 360 billion Euro;

- the annual percentage of the value of procurements in GDP: approx. $10-15 \%$ (Solbach, T. 2018).

According to the same author, the procurement system is decentralized on three levels: federal, regional and local / municipal, the weight of the number of contracting authorities being of approx. $12 \%$ at federal level, approx. $30 \%$ at regional level and approx. 58\% at local / municipal level. Interestingly, procurement procedures below EU value thresholds represent approximately $90 \%$ of the total number of procedures and $75 \%$ of the total value of procurements whereas the procedures under the EU thresholds represent approx. $10 \%$ of the total number of procedures and $25 \%$ of the total procurements (Table 1). 
Structure of the German procurement system

Table 1

\begin{tabular}{|c|l|c|c|}
\hline No. & \multicolumn{1}{|c|}{ Indicator / Type of procedures } & $\begin{array}{c}\text { Procedures below } \\
\text { EU thresholds }\end{array}$ & $\begin{array}{c}\text { Procedures above } \\
\text { EU thresholds }\end{array}$ \\
\hline 1 & $\begin{array}{l}\text { Weight of the number of procedures } \\
\text { from the total number of procedures }\end{array}$ & $90 \%$ & $10 \%$ \\
\hline 2 & $\begin{array}{l}\text { Weight of the value of procedures in the } \\
\text { total value of procurements }\end{array}$ & $75 \%$ & $25 \%$ \\
\hline
\end{tabular}

Source: Solbach, T. (2018)

Given that $90 \%$ of the total number of procedures (namely a weight of $75 \%$ of the total value) are procedures below EU thresholds, Germany has a fast, flexible, efficient and low-bureaucratic procurement system.

\section{Comparative situation of types of procedures in Germany and Romania}

Table 2

\begin{tabular}{|c|l|c|c|c|c|}
\hline \multirow{2}{*}{ No. } & Indicator / Type of procedures & \multicolumn{2}{|c|}{$\begin{array}{c}\text { Procedures below EU } \\
\text { thresholds }\end{array}$} & \multicolumn{2}{c|}{$\begin{array}{c}\text { Procedures above } \\
\text { EU thresholds }\end{array}$} \\
\cline { 3 - 6 } & Germany & Romania & Germany & Romania \\
\hline 1 & $\begin{array}{l}\text { Weight of the number of } \\
\text { procedures from the total number } \\
\text { of procedures }\end{array}$ & $90 \%$ & $68 \%$ & $10 \%$ & $32 \%$ \\
\hline 2 & $\begin{array}{l}\text { Weight of the value of procedures } \\
\text { in the total value of procurements }\end{array}$ & $75 \%$ & $17 \%$ & $25 \%$ & $83 \%$ \\
\hline
\end{tabular}

Sources: Solbach, T. (2018); National Agency for Public Procurement (ANAP) - Indicators

to monitor the effectiveness of procurement procedures completed by contract / framework agreement in 2017

By comparison, it should be noted that in 2017, in Romania the weight of the number of procedures under the EU threshold was of $68 \%$ (compared to $90 \%$ in Germany), but the weight of the threshold value was only $17 \%$ (compared to $75 \%$ in Germany) (Table 2).

The graphical representation of the weights of the number of procedures and of the values of the procedures below / above the value threshold at EU level is presented in Figure 1. 


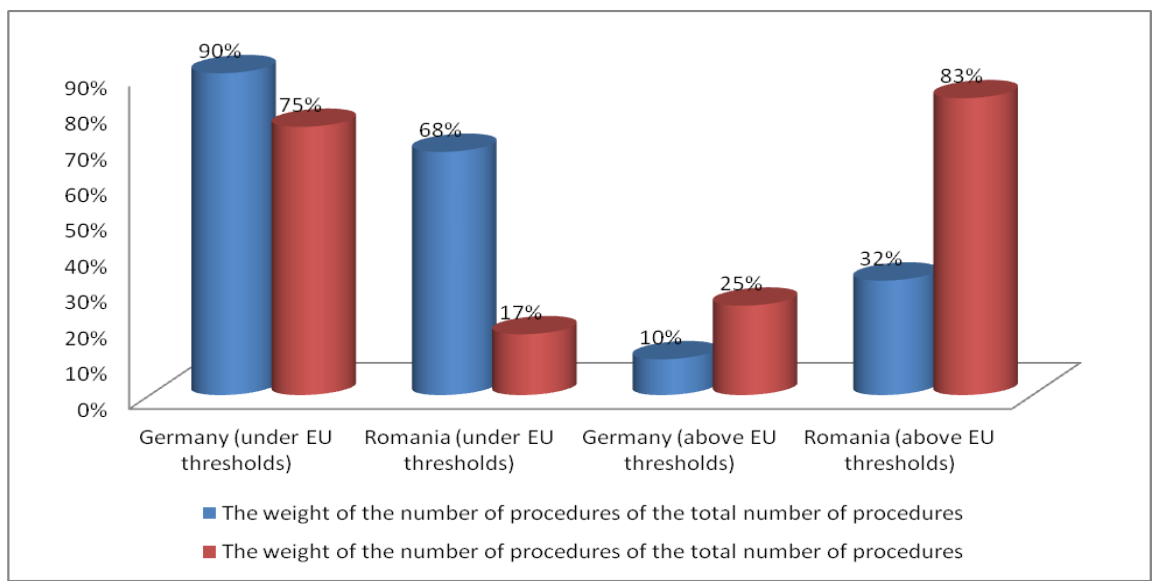

Figure 1: Graphical representation of the weights of the number of procedures and of the values of the procedures below / above the EU threshold

Source: Based on the data in Table 2

According to BMWi (2018), as of January 1, 2018, the EU thresholds values (without VAT) for the procurement procedures in Germany are the following:

- 5,548,000 Euro for works;

- 443,000 Euro for sectoral or defence procurement;

- $\quad 144,000$ Euro for products and services purchased by central or federal authorities;

- 221,000 Euro for other product and service contracts (BMWi, 2018).

The comparative situation of value thresholds for procedures in Germany and Romania is presented in Table 3.

Comparative situation of value thresholds in Germany and Romania

\begin{tabular}{|c|c|c|c|}
\hline \multirow{2}{*}{ No. } & \multirow{2}{*}{ Object of procurement procedure } & \multicolumn{2}{|c|}{ Value thresholds } \\
\cline { 3 - 4 } & Works & Germany & Romania \\
\hline 1 & Sectoral procurement & 448,000 euro & $\begin{array}{c}24,977,096 \text { lei } \\
5,236,288 \text { euro }\end{array}$ \\
\hline 2 & Defence & 443,000 euro & $\begin{array}{c}1,858,177 \text { lei } \\
389,554 \text { euro }\end{array}$ \\
\hline 3 & Social services & 144,000 euro & $\begin{array}{c}648,288 \text { lei } \\
139,909 \text { euro }\end{array}$ \\
\hline 4 & $\begin{array}{c}\text { Products or services purchased by central / } \\
\text { federal authorities }\end{array}$ & 750,000 euro & $\begin{array}{c}3,376,500 \text { lei } \\
707,861 \text { euro }\end{array}$ \\
\hline 5 & Socal / County / Municipal Councils, & - & 994,942 lei \\
\hline 6 & institutions subordinated to them & 221,000 euro & - \\
\hline 7 & Other product and service contracts & & \\
\hline
\end{tabular}

Note: The Romanian thresholds in Euro were calculated at an exchange rate of 1 Euro $=4.77$ lei.

Sources: BMWi, (2018); Romanian Law no 98/2016

$66 \quad$ Review of International Comparative Management

Volume 20, Issue 1, March 2019 
As it can be seen, the value thresholds for procedures with a common object of procurement are approximately equal, which is normal, given that both countries comply with EU directives.

\section{Comparative situation of the procurement principles in Romania and Germany}

Table 4

\begin{tabular}{|c|c|c|}
\hline \multirow{2}{*}{ No. } & \multicolumn{2}{|c|}{ Public Procurement Principles } \\
\cline { 2 - 3 } & Romania & Germany \\
\hline 1 & equal treatment & equal treatment \\
\hline 2 & non-discrimination & non-discrimination \\
\hline 3 & transparency & transparency \\
\hline 4 & proportionality & interest for small and medium-sized enterprises \\
\hline 5 & mutual recognition & competition \\
\hline 6 & assuming responsibility & eProcurement \\
\hline 7 & - &
\end{tabular}

Sources: Solbach, T. (2018); Romanian Law no 98/2016

According to Solbach, T. (2018), the principles of public procurement in Germany are: transparency, competition (more than one tenderer), nondiscrimination, equal treatment (for European and international tenderers), interest for small and medium enterprises (the division of the object of procedure in batches being mandatory, applying the principle of proportionality), sustainability and eProcurement. Table 4 presents a comparative situation regarding the procurement principles in Romania and Germany.

The comparative analysis of procurement principles in Romania and Germany reveals that three principles are common to both countries and four of the German principles make public procurement more effective, namely:

- favouring small and medium-sized enterprises that are the engine of any national economy;

- ensuring the durability of procurement (sustainability) results, through the purchase of quality products;

- promoting competition that leads to lower prices and higher procurement efficiency;

- encouraging e-procurement which is faster, more transparent and more efficient.

The German public procurement award criterion is the "most economically advantageous tender" (MEAT- most economically advantageous tender) which must be identified by the purchasers at least on the basis of the lowest price or the lowest cost (including the lowest life cycle cost). Other assessment factors can be quality, social aspects, environmental aspects, innovation, etc. Sustainability in public procurement in Germany can mainly refer to environmental and social issues. Sustainability can be transposed into procurement procedures by requiring specific technical specifications, award criteria and dedicated contractual clauses. It should be noted that sustainability is treated only as a principle, and there is no 
general obligation on contracting authorities to include issues related to it (Solbach, T., 2018).

\section{Comparison of the award criteria and the assessment factors in Germany and Romania}

Table 5

\begin{tabular}{|c|c|c|c|}
\hline \multicolumn{2}{|r|}{ Germany } & \multicolumn{2}{|r|}{ Romania } \\
\hline Award criteria & Assessment factors & $\begin{array}{l}\text { Award } \\
\text { criteria }\end{array}$ & Assessment factors \\
\hline $\begin{array}{l}\text { the most } \\
\text { economically } \\
\text { advantageous } \\
\text { tender, which } \\
\text { may be the } \\
\text { lowest price or } \\
\text { the lowest cost }\end{array}$ & $\begin{array}{l}\text { quality, sustainability, social } \\
\text { aspects, environmental } \\
\text { aspects, innovation, } \\
\text { functional features, aesthetic } \\
\text { features, operating costs, } \\
\text { delivery chart (time), cost- } \\
\text { effectiveness ratio }\end{array}$ & $\begin{array}{l}\text { 1. the } \\
\text { lowest } \\
\text { price }\end{array}$ & - \\
\hline- & - & $\begin{array}{l}\text { 2. the } \\
\text { lowest } \\
\text { cost }\end{array}$ & - \\
\hline- & - & $\begin{array}{c}\text { 3. best } \\
\text { quality- } \\
\text { price ratio }\end{array}$ & $\begin{array}{l}\text { quality, functional and } \\
\text { aesthetic, social, } \\
\text { environmental characteristics, } \\
\text { technical advantages, sales } \\
\text { conditions, experience, }\end{array}$ \\
\hline- & - & $\begin{array}{l}\text { 4. best } \\
\text { quality- } \\
\text { cost ratio }\end{array}$ & $\begin{array}{l}\text { qualification and organization } \\
\text { of staff, sales conditions, post- } \\
\text { sale services, combating } \\
\text { unemployment, production } \\
\text { process, marketing, specific } \\
\text { processes }\end{array}$ \\
\hline
\end{tabular}

Sources: Solbach, T. (2018); Romanian Law no 98/2016

The comparative situation of the award criteria and the assessment factors used in Germany and Romania are presented in Table 5.

Centralized procurements are carried out at the federal level by the Federal Procurement Office of the Ministry of Interior (BeschA - Beschaffungsamt des Bundesministeriums des Inneren) and by the Federal Office of Bundeswehr Equipment, Information, Technology and In- Service Support (BAAINB).

Particular attention is paid to professionalisation of purchasers, taking steps to improve their training, some universities having master programs dedicated to the University of Munich, the Federal Academy of Public Administration and some academies at the regional level (Solbach, T., 2018). 


\section{Similarities in initiating procedures, evaluating tenders, awarding tenders}

and filing complaints in Germany and Romania

Table 6

\begin{tabular}{|c|c|}
\hline No. & Similarities \\
\hline 1 & $\begin{array}{l}\text { the initiation of procedures above EU thresholds is published in Official Journal of } \\
\text { the EU (OJEU) }\end{array}$ \\
\hline 2 & $\begin{array}{l}\text { the contract award rule is open procedures (open bid) or restricted procedures } \\
\text { where the minimum number of tenderers is five (restricted bid) }\end{array}$ \\
\hline 3 & $\begin{array}{l}\text { the framework contract may be concluded with one or more tenderers, in the } \\
\text { second case the competition shall be resumed prior to the award of the subsequent } \\
\text { contracts }\end{array}$ \\
\hline 4 & $\begin{array}{l}\text { the contracting authority is obliged to divide the object of the procedure into } \\
\text { batches and may limit the number of batches attributable to the same contractor }\end{array}$ \\
\hline 5 & $\begin{array}{l}\text { the contracting authority has the right to choose whether or not to accept } \\
\text { alternative tenders }\end{array}$ \\
\hline 6 & $\begin{array}{l}\text { award criteria and assessment factors should be mentioned in the awarding } \\
\text { documentation and cannot be changed during the course of the procedure or later }\end{array}$ \\
\hline 7 & $\begin{array}{l}\text { the contracting authority through the members of the tender evaluation committee } \\
\text { must be independent, neutral and impartial }\end{array}$ \\
\hline 8 & $\begin{array}{l}\text { the conflict of interest applies in both countries and has the same cases of } \\
\text { exclusion from the award procedure of a member of the evaluation committee or } \\
\text { of a tenderer }\end{array}$ \\
\hline 9 & $\begin{array}{l}\text { two tenderers with links between themselves belonging to the same parent } \\
\text { company or belonging to one another cannot submit two separate tenders or a } \\
\text { separate tender and a tender in association because these are considered to be non- } \\
\text { competitive behaviour }\end{array}$ \\
\hline 10 & $\begin{array}{l}\text { the tenderer whose tender has been declared unsuccessful must be informed by the } \\
\text { contracting authority of the name of the successful tenderer, the reasons why the } \\
\text { tender was selected (the advantages of the winning tender against the unsuccessful } \\
\text { tender). Contracts cannot be concluded until a } 10 \text {-calendar day waiting period (in } \\
\text { both countries) has passed since the date of receipt of the above-mentioned } \\
\text { notification }\end{array}$ \\
\hline 11 & $\begin{array}{l}\text { for tenders which have an unusually low price, contracting authorities must seek } \\
\text { clarification from tenderers, but in Germany such a tender is considered to be a } \\
\text { tender which has a price } 10-20 \% \text { lower than the second tender while in Romania } \\
\text { the value of the unusually low price is left to the discretion of the contracting } \\
\text { authority }\end{array}$ \\
\hline 12 & $\begin{array}{l}\text { In both states, complaints are filed in a two-tier system: at the first level there are } \\
\text { institutions with administrative-jurisdictional powers such as the Federal Review } \\
\text { Chamber for procurement procedures (FRC) in Germany and National Council for } \\
\text { Settlement of Appeals (NCSA) in Romania, and the courts of appeal are at the } \\
\text { second level. In Germany, the appeals filed with FRC shall be settled within a } \\
\text { period of } 2 \text { to } 4 \text { months (in Romania the average time for settling appeals at NCSA } \\
\text { in } 2017 \text { was of } 29 \text { calendar days) and at the courts of appeal within a period of } 2 \text { to } \\
6 \text { months }\end{array}$ \\
\hline 13 & $\begin{array}{l}\text { for lodging appeals at both levels, the claimant is required a guarantee (bail in } \\
\text { Romania) the amount of which is directly proportional to the estimated / awarded } \\
\text { value of the contract, guarantee which is forfeited if the appeal is rejected }\end{array}$ \\
\hline
\end{tabular}




\begin{tabular}{|l|l|}
\hline No. & \multicolumn{1}{c|}{ Similarities } \\
\hline 14 & $\begin{array}{l}\text { a new procedure is not required to be initiated if the successful tenderer is taken } \\
\text { over or merged with another company, if the nature of the contract is not changed, } \\
\text { if the additional products that are deemed to be purchased make the value of the } \\
\text { contract to be above EU thresholds }\end{array}$ \\
\hline 15 & $\begin{array}{l}\text { In Germany, additional products / services / works can be purchased by drawing } \\
\text { up an addendum for up to 10\% for products / services of the initial value of the } \\
\text { contract and no more than 15\% for works, in Romania both percentages being } \\
50 \%\end{array}$
\end{tabular}

Sources: Solbach, T. (2018); Romanian Law no 98/2016

Given that both Germany and Romania comply with the EU Directives, as regards initiating procedures, evaluating tenders, awarding tenders and filing complaints, there are a number of similarities that are presented in Table 6 .

\section{The public procurement system in France}

The relevant legislation in France is made up of Ordinance no. 2015-899 of 23.07.2015 which contains the overall legal framework for public procurement in France, Decree no. 2016-360 of 25.03.2016, which contains the details and rules for the application of the Ordinance and Decree no.2017-516 of 10.04.2017 which amended Decree 2016-360 of 25.03.2016. As the rest of the countries in the EU, French procurement legislation transposes rules at European level. These legal provisions refer to $\mathrm{EU}$ and to international agreements where $\mathrm{EU}$ is part (Holterbach, K., Dubrulle, J., B., 2018).

Also, according to the same authors, the principles of public procurement in France are:

- transparency by which contracting authorities must communicate in advance all important elements of the procurement;

- equal treatment by which contracting authorities will make available the same information to potential tenderers;

- open, unrestricted access to the procurement procedure: public announcement and competition are mandatory to allow potential tenderers to compete;

- the efficiency of using public funds (Holterbach, K. and Dubrulle, J., B., 2018).

\section{Comparison between the principles of public procurement in Romania and France}

Table 7

\begin{tabular}{|c|c|c|}
\hline \multirow{2}{*}{ No. } & \multicolumn{2}{|c|}{ Public Procurement Principles } \\
\cline { 2 - 3 } & Romania & France \\
\hline 1 & equal treatment & equal treatment \\
\hline 2 & non-discrimination & open access \\
\hline 3 & transparency & transparency \\
\hline
\end{tabular}




\begin{tabular}{|c|c|c|}
\hline \multirow{2}{*}{ No. } & \multicolumn{2}{|c|}{ Public Procurement Principles } \\
\cline { 2 - 3 } & Romania & France \\
\hline 4 & proportionality & - \\
\hline 5 & mutual recognition & - \\
\hline 6 & assuming responsibility & - \\
\hline 7 & economic and social efficiency (purpose) & efficiency of public funds use \\
\hline
\end{tabular}

Sources: Holterbach, K., Dubrulle, J., B., (2018); Romanian Law no 98/2016

Table 7 presents a comparative situation regarding the procurement principles in Romania and France. It should be mentioned that the economic and social efficiency of the procurement of goods, services or works is the purpose of the public procurement legislation in Romania (the efficiency of the use of public funds was a principle in the 2006-2016 legislation, namely in GEO 34/2006).

The comparative analysis of the procurement principles in Romania and France reveals that two principles are common to both countries (equal treatment and transparency) and efficiency which is a principle in France, in Romania is the purpose of procurement. This aspect is important because when a particular situation / problem occurs (which is not regulated), it must be resolved in accordance with the principles in each country. In other words, the principles must always be respected, in the conditions in which the purpose can be reached or not, as the case may be. From this point of view, the legislation in France is superior to that in Romania, aiming to obtain the maximum effects for consumed resources (budgetary funds).

In France, that ordinance and decree mentioned apply where a contracting authority wishes to purchase services, works or products the value of which exceeds 25,000 Euro. The value thresholds (VAT excluded) for the procurement procedures in France are the following:

- 135,000 Euro for products and services purchased by state authorities and administrative institutions;

- 209,000 Euro for products or services purchased by local authorities and their administrative institutions;

- 418,000 Euro for sectoral or defence purchases

$-5,225,000$ Euro for works (Holterbach, K., Dubrulle, J., B., 2018).

The comparative situation of value thresholds for procedures in France and Romania is presented in Table 8.

Comparative situation of value thresholds in France and Romania

\begin{tabular}{|c|l|c|r|}
\multicolumn{2}{|c}{ Table 8 } \\
\hline \multirow{2}{*}{ No. } & \multicolumn{1}{|c|}{ Object of procurement procedure } & Value thresholds \\
\cline { 3 - 4 } & Works & France & \multicolumn{1}{c|}{ Romania } \\
\hline 2 & Sectoral procurement & $\begin{array}{c}5,225,000 \\
\text { euro }\end{array}$ & $\begin{array}{r}24,977,096 \text { lei } \\
5,236,288 \text { euro }\end{array}$ \\
\hline 3 & Defence & 418,000 euro & $\begin{array}{r}1,858,177 \text { lei } \\
389,554 \text { euro }\end{array}$ \\
\hline 4 & $\begin{array}{l}\text { Products and services purchased by state } \\
\text { authorities and their administrative institutions }\end{array}$ & 418,000 euro & 428,000 euro \\
\hline
\end{tabular}

Review of International Comparative Management

Volume 20, Issue 1, March 2019

71 


\begin{tabular}{|c|c|c|c|}
\hline \multirow{2}{*}{ No. } & \multirow{2}{*}{ Object of procurement procedure } & \multicolumn{2}{|c|}{ Value thresholds } \\
\hline & & France & Romania \\
\hline 5 & $\begin{array}{l}\text { Products or services purchased by local } \\
\text { authorities and their administrative institutions }\end{array}$ & 209,000 euro & $\begin{array}{r}994,942 \text { lei } \\
208,583 \text { euro } \\
\end{array}$ \\
\hline 6 & Social services & - & $\begin{array}{l}3,376,500 \text { lei } \\
707,861 \text { euro }\end{array}$ \\
\hline 7 & Direct procurement (not procedure) & 25,000 euro & $\begin{array}{r}135,060 \text { lei } \\
28,314 \text { euro }\end{array}$ \\
\hline
\end{tabular}

Sources: Holterbach, K., Dubrulle, J., B., (2018); Romanian Law no 98/2016

Note: The Romanian thresholds in Euro were calculated at an exchange rate of 1 Euro $=4.77$ lei.

As it can be seen, the value thresholds for procedures with a common procurement object are roughly equal, which is normal, given that both countries comply with EU directives.

When the estimated value does not exceed 25,000 Euro it is not necessary to conduct a procedure (the equivalent of direct procurements in Romania). If the estimated value is between 25,000 Euro and the thresholds mentioned, the contracting authority may conduct a procedure in compliance with the principles of equal treatment, open access and transparency (without this requirement being an obligation), provided that the simplified procedure is applied in Romania. When the estimated value exceeds the thresholds in lines 1-5 of the table above, an award procedure should be applied (Holterbach, K., Dubrulle, J., B., 2018).

According to Holterbach, K. and Dubrulle, J., B., (2018), as in Romania, in France, award procedures can take the following forms:

- a call to tender ("appel d'offre") - the equivalent of the invitation notice in Romania - a procedure that can be open or restricted;

- a competitive procedure with negotiation;

- competitive dialogue (Holterbach, K. and Dubrulle, J., B., (2018).

The comparative situation of the types of procedures in France and Romania is shown in Table 9.

Comparative situation of the types of proceedings in France and Romania

\begin{tabular}{|c|c|}
\hline \multicolumn{2}{|c|}{ Procedure type } \\
\hline France & Romania \\
\hline Open procedure & Open bid \\
\hline Restricted procedure & Restricted bid \\
\hline Competitive procedure with negotiation & Competitive negotiation \\
\hline- & Competitive dialogue \\
\hline Competitive dialogue & Solution bid \\
\hline One procedure can be applied or not & The procedure applicable to social \\
\hline- & services and other specific services \\
\hline- & The partnership for innovation \\
\hline- &
\end{tabular}

Sources: Holterbach, K., Dubrulle, J., B., (2018); Romanian Law no 98/2016 
As it can be seen, the types of procedures in Romania are more numerous than those in France and are more suited to specific areas (social services, innovative products, etc.).

Also, as in our country, in France, award criteria, assessment factors, their weights, or calculation algorithm are published in the award documentation and cannot be changed during the procedure. The award criteria in French law are:

- the "lowest price" traditional criterion where the tenderer which presents the lowest price is declared the winner;

- "the best quality-price ratio";

- the "lowest cost", the cost being set on the life cycle of the product and consisting of the manufacturing cost, the operating (use) cost, the maintenance cost and the end-of-life cycle cost (Holterbach, K., Dubrulle , J., B., 2018).

Comparative situation of the award criteria in France and Romania

Table 10

\begin{tabular}{|c|c|}
\hline \multicolumn{2}{|c|}{ Award criteria } \\
\hline France & Romania \\
\hline the lowest price & the lowest price \\
\hline the lowest cost & the lowest cost \\
\hline the best quality - price ratio & the best quality - price ratio \\
\hline - & the best quality - cost ratio \\
\hline
\end{tabular}

Sources: Holterbach, K., Dubrulle, J., B., (2018); Romanian Law no 98/2016

In France, tenders are often analysed using assessment factors such as quality, delivery term, the quality of the tenderer's team performing the contract, sustainable development aspects, environmental protection, social protection, social inclusion, biodiversity. (Holterbach, K., Dubrulle, J., B., 2018).

The comparative situation of the award criteria used in France and Romania is presented in Table 10.

As it can be seen, in France there is no criterion of the best quality-cost ratio. This is not a major disadvantage of French law, because in Romania this criterion was very little used in 2017, that is, it was used to award 25 procedures (weight $0.13 \%$ of the total). The lowest cost criterion was used in Romania in 2017 to award 8 procedures (weight of only $0.04 \%$ ).

A difference between the two legislations is the way of interpreting tenders with an unusually low price. While in Romania the value of the unusually low price is left to the discretion of the contracting authority, in France it is calculated as follows:

- first, the contracting authority calculates an average of the values of the received tenders excluding the highest tender received and the lowest tender received;

- then, after the contracting authority has excluded all tenders exceeding the first average by $20 \%$, it makes a second average with the remaining tenders. Tenders that are $15 \%$ lower than the second average are 
considered to present a tender with an unusually low price (Holterbach,

K., Dubrulle, J., B., 2018).

From what it can be seen, the way of calculating the unusually low price in France is very precise without being left to the arbitrary appreciation of the contracting authority as in Romania. In Romania, a contracting authority can become "more friendly" with the lower tender of a tenderer so as not to ask the tenderer to clarify the low tendered price. From this point of view, with regard to the unusually low price, the French legislation is superior to the Romanian one because it eliminates arbitrariness and duly applies the principle of equal treatment of tenderers.

\section{Comparative situation of the main characteristics of public procurement systems in France and Romania}

Table 11

\begin{tabular}{|c|c|c|c|}
\hline No. & Characteristic & France (2013) & Romania (2017) \\
\hline 1 & $\begin{array}{l}\text { Procurement weight from } \\
\text { GDP }\end{array}$ & $15 \%$ & $7 \%$ \\
\hline 2 & $\begin{array}{l}\text { Number of contracting } \\
\text { authorities }\end{array}$ & 132,652 & 20,773 (in 2018) \\
\hline 3 & Number of procedures & $\begin{array}{c}40,516 \text { (published in } \\
\text { JOUE) }\end{array}$ & 19,923 (total) \\
\hline 4 & Open procedures & $76 \%$ & $99 \%$ \\
\hline 5 & Restricted procedures & $3 \%$ & $0.22 \%$ \\
\hline 6 & Negotiations & $12 \%$ & $0.41 \%$ \\
\hline 7 & Procurement value & 306.98 billion euro & 12.75 billion euro \\
\hline 8 & Service contracts weight & $52 \%$ & $13 \%$ \\
\hline 9 & Works contracts weight & $17 \%$ & $6 \%$ \\
\hline 10 & Product contracts weight & $31 \%$ & $81 \%$ \\
\hline 11 & Lowest price criterion weight & $4 \%$ & $92 \%$ \\
\hline 12 & Other award criteria & $96 \%$ & $8 \%$ \\
\hline 13 & $\begin{array}{l}\text { Average duration of } \\
\text { procurement processes }\end{array}$ & 91.5 days & $\begin{array}{c}91 \text { days (Ex-Ante } \\
\text { unverified procedures) } \\
114 \text { days (Ex-Ante } \\
\text { verified procedures) }\end{array}$ \\
\hline 14 & $\begin{array}{l}\text { Weight of procedures with a } \\
\text { single tenderer }\end{array}$ & $14 \%$ & ( \\
\hline 15 & $\begin{array}{l}\text { Procedures won by foreign } \\
\text { companies }\end{array}$ & $2 \%$ & $0.0008 \%$ \\
\hline 16 & Centralized procurement & YES, U.G.A.P. & $\begin{array}{c}\text { YES, the National Office } \\
\text { for Centralized } \\
\text { Procurement (ONAC), } \\
\text { inoperative }\end{array}$ \\
\hline 17 & Number of purchasers & approx. 200,000 & unknown \\
\hline 18 & Central Training Institutions & $\begin{array}{l}\text { YES, ENA, INET, } \\
\text { CNFPT, EHESP }\end{array}$ & $\mathrm{NO}$ \\
\hline
\end{tabular}

Sources: SACEU - France, (2014) - Public procurement - Study on administrative capacity in the EU - France Country Profile; National Agency for Public Procurement (ANAP) Indicators to monitor the effectiveness of procurement procedures completed by contract / framework contract in 2017 
The system of public procurement in France is under the responsibility of the Ministry of Economy and Finance (MINEFI - Ministere de l'Economie des Finances et de l'Industrie), with a centralized procurement agency, Union for Grouping Procurement (UGAP - Union des Groupements d'Achats Publics) at national level.

In France, procurement procedures are carried out by approximately 200,000 workers from the central government, regional governments, municipal departments, structures, inter-municipal structures, and health institutions. The public procurement staff is trained in four main public service schools: at central level, the National Administration School (ENA- Ecole Nationale d'Aministration), and at the territorial level, the National Institute for Territorial Studies (INET- Institut National de Etudes Territoriales), The National Center for Territorial Public Service (CNFPT- Centre National de la Fonction Publique Territoriale) and for health services (hospitals) the National School of Public Health (EHESP - Ecole des Hautes Etudes en Sante Publique (SACEU - France, 2014).

The comparative situation of the main characteristics of the public procurement systems in France and Romania is presented in Table 11.

From the analysis of the above situation it can be noticed that the procurement system in France is much bigger than the one in Romania, in terms of the value of the procurements, the number of contracting authorities and the number of purchasers. The weight of procurements of GDP is twice as high and the number of contracting authorities is approximately six times higher in France than in Romania.

Significant differences between the two systems are found in terms of:

- the weight of open procedures (76\% in France and 99\% in Romania) and the weight of negotiations (12\% in France and $0.41 \%$ in Romania). From this point of view, the Romanian procurement system is more suited to open procedures, characterized by superior competitiveness;

- In France, service contracts have a weight over 3 times higher than in Romania, which may indicate an opportunity to develop service procurements in Romania, to the detriment of those for products (which in Romania are three times more numerous than in France, $81 \%$ vs. $31 \%$ );

- the weight of the procedures awarded with a single tender is twice higher in Romania (27\%) than in France (14\%), which shows the need to introduce measures to increase the number of tenders received in the Romanian procedures in order to get the most competitive prices;

- in France there is a centralized procurement agency UGAP founded in 1968, while in Romania the National Office for Centralized Procurement (ONAC) was set up in 2018 and is currently inoperable, which shows a missed opportunity in Romania to carry out centralized procurement which, due to the aggregate demand, would be able to lead to lower prices and higher efficiency; 
- the number of purchasers in France is of approx. 200,000, this number being unknown in Romania, which shows deficiencies in Romania in terms of their preparation and reformation (introduction of centralized procurement, in conjunction with the reduction in the number of purchasers);

- In France, there are four central state institutions that provide instruction and training to purchasers, provided that there is no such institution in Romania, with all the consequences arising from this factual situation (lack of specialized training of purchasers, adapted to the needs of the contracting authorities and problems in the field, low attractiveness of the procurement field for young graduates, etc.).

The average duration of a procedure is equal in both countries, 91 days, and the weight of procedures won by foreign companies is very small.

\section{Conclusions}

The article describes an analysis of the main characteristics of the public procurement systems in Germany and France, compared to the public procurement system in Romania.

The study found that, in comparison with the public procurement system in Romania, due to the much larger share of procedures below the EU thresholds, the German public procurement system is faster, more flexible, efficient and less bureaucratic.

Also, the German system favours participation in procurement procedures for small and medium-sized enterprises, ensures the sustainability of procurement results by buying quality products, promotes competition, and encourages eprocurement.

In Germany centralized procurements are carried out by two federal agencies, while in Romania, the National Office for Centralized Procurement (ONAC), which was set up in 2018, is currently inoperable. The instruction and training of purchasers in Germany is carried out through state universities or academies, while in Romania there are no such training programs.

Compared to the Romanian system, the public procurement system in France is more inclined to the efficient use of public funds, with fewer procedures, being able to apply or not (at the choice of the French contracting authority) a procedure such as the simplified procedure in Romania, as the tender assessment factors may contain aspects related to sustainable development, environmental protection, social protection, social inclusion and even biodiversity.

The study also shows that in the French system, service contracts have a weight over 3 times higher than in Romania, which may indicate an opportunity to develop service procurement in Romania, and the weight of procedures awarded with a single tender received is twice higher in Romania than in France, which shows the need to introduce measures to increase competition and, implicitly, the

$76 \quad$ Review of International Comparative Management

Volume 20, Issue 1, March 2019 
number of tenders received in the Romanian procedures in order to obtain the most competitive prices.

In France there is a centralized procurement agency UGAP (set up since 1968), while in Romania, the National Office for Centralized Procurement (ONAC) is not functional. In addition, there are four central state institutions in France that provide instruction and training to purchasers, while there is no such institution in Romania.

\section{References}

BMWi - Federal Ministry for Economic Affairs and Energy (2018), https://www.bmwi.de/Redaktion/EN/Dossier/public-procurement.html, Accesed 1 december 2018

BWB (2006), p. 4. cited in Thai, K. V. et al (2009) - International Handbook of Public Procurement, p. 311, Ed. Taylor \& Francis Group

EC - European Commission, (2019) - Single Market and Standards: Public Procurement, https://ec.europa.eu/growth/single-market/public-procurement_ en, Accesed 1 january 2019

Holterbach, K., Dubrulle, J., B. (2018) Public Procurement 2018/France (ICLG Internațional Comparative Legal Guides), https://iclg.com/practiceareas/public-procurement-laws-and-regulations/france, Accesed 16 december 2018

National Agency for Public Procurement (ANAP) - Indicatorii de monitorizare a eficienței procedurilor de achiziție publică finalizate prin contract/acordcadru in anul 2017, http://anap.gov.ro/web/wp-content/uploads/ 2018/06/Indicatorii-de-monitorizare-a-eficien\%C8\%9Bei-procedurilor-deachizi\%C8\%9Bie-public\%C4\%83-finalizate-prin-contract-sau-acordcadru-\%C3\%AEn-2017.pdf, Accesed 2 december 2018

Procurement Agency of the Federal Ministry of the Interior (2005) cited in Thai, K. V. et al (2009) - International Handbook of Public Procurement, p. 312, Ed. Taylor \& Francis Group

Solbach, T., (2018) - Public procurement in Germany, pp. 3-16, http://www.europarl.europa.eu/cmsdata/138604/06\%20-\%20SOLBACH $\% 20-\% 20$ Public\%20Procurement $\% 20$ in $\% 20$ Germany.pdf, Accesed 1 december 2018

SACEU - France, (2014) - Public procurement - Study on administrative capacity in the EU - France Country Profile, pp. 1-5, https://ec.europa.eu/regional _policy/sources/policy/how/improving-investment/public-

procurement/study/country_profile/fr.pdf, Accesed 2 december 2018

Thai, K., V. et al (2009) - International Handbook of Public Procurement, pp. 69-70, Ed. Taylor \& Francis Group 